\title{
Binding of wild-type and mutant forms of P53 protein from human tumors to a specific DNA sequence of the first intron of the H-ras oncogene
}

\author{
V. ZOUMPOURLIS ${ }^{1}$, G. ZACHOS $^{1,2}$, T.D. HALAZONETIS ${ }^{3}$, M. ERGAZAKI ${ }^{1,2}$ and D.A. SPANDIDOS ${ }^{1,2}$
}

\begin{abstract}
${ }^{1}$ Institute of Biological Research and Biotechnology, National Hellenic Research Foundation, Athens, Greece; ${ }^{2}$ Medical School, University of Crete, Heraklion, Greece; ${ }^{3}$ Department of Molecular Oncology, the Wistar Institute, Philadelphia, PA 19104, USA
\end{abstract}

Contributed by D.A. Spandidos, July 28, 1995

\begin{abstract}
. p53 is the most frequent target for genetic alterations in a wide variety of human cancers. The product of the p53 tumor suppressor gene binds to DNA and activates transcription from promoters containing its consensus binding site. In the accompanying paper we have found that P53 tumor suppressor protein recognizes specifically a transcriptional element within the human H-ras protooncogene (Spandidos DA, et al, Int J Oncol 7: 1029-1034, 1995). We transfected Saos-2 cells, which are p53-null cells, with plasmids encoding for the wild type (wt) and for one 'hot spot' mutant (mt) of the p53 gene (H 273). Using the resulted nuclear extracts for gel retardation assays, we showed binding of both the wild-type and the mutant form of p53 to the H-ras DNA. Furthermore, using nuclear extracts from head and neck tumors and from adjacent normal tissues in gel retardation assays, we found binding of both the wildtype and the p53 mutant in the same responsive element of the $\mathrm{H}-\mathrm{ras}$ oncogene. These experimental results suggest a direct role of p53 in regulation of H-ras. Identification of cellular proto-oncogenes as mediators of the transcriptional effects of wild-type and mutant forms of p53 gene, will be a step towards a better understanding of the role of oncogenes and onco-suppressor genes in tumor promotion.
\end{abstract}

\section{Introduction}

The p53 gene is localized to $17 \mathrm{q} 13$ chromosome and encodes a 393 amino-acid protein which functions as a trans-acting transcriptional factor controlling the expression of genes important in transcription, DNA synthesis and repair $(1,2)$, cell differentiation (3) and apoptosis (4). Wild-type p53 mediates these actions by binding specifically to certain sites found in human genomic DNA (5). All of these p53 responsive elements share a repeat of the loose consensus sequence, the ten base pair $5^{\prime}-(\mathrm{Pu})_{3} \mathrm{C}(\mathrm{A} / \mathrm{T})(\mathrm{T} / \mathrm{A}) \mathrm{G}(\mathrm{Py})_{3}-3^{\prime}$

Correspondence to: Professor D.A. Spandidos, Institute of Biological Research and Biotechnology, National Hellenic Research Foundation, 48 Vas. Constantinou Avenue, 11635 Athens, Greece

Key words: $\mathrm{P} 53$ protein, H-ras oncogene motif $(5,6)$. Such sites have been located in regulatory elements of the gadd45 (7), waf-l/cip-1 (8), and $m d m-2$ (9) genes. In order to bind these regions, oligomerization of the P53 protein is required, although monomeric P53 can also bind DNA, depending on the protein concentration and the nature of the P53 binding site $(10,11)$.

It is not surprising that such a molecule, which stands in the crossroad of so many vital cellular functions is inactivated in more than half of all human tumors (12). The most important mechanism to overcome the p53 tumor supressor barriers is alteration of the gene, mostly via mutations, although complex formation of wt p53 with viral and cellular gene products also abrogates p53 functions (13-16).

H-ras gene is a member of the family of ras protooncogenes. The gene product of $\mathrm{H}-\mathrm{ras}$, p21, is localized in the inner side of the cell membrane and acts in the normal signal transduction pathway as a GTP-binding protein. Genes of the ras family are implicated in human tumorigenesis both through mutations and overexpression (17). Since overexpression of activated ras genes may cause oncogenic transformation $(18,19)$ and expression of the normal H-ras gene can act as an onco-supressor (20), it is important to understand the regulation of ras genes. It has been shown that mutant p53 co-operates with ras for cellular transformation $(21,22)$ and that activated $\mathrm{H}$-ras is necessary to overcome the onco-supressor function of the wt-p53 $(23,24)$.

Previous studies (25) identified within the H-ras gene three putative p53 binding half sites, two of which are contiguous and contain a ten base core which perfectly matches the p53 CON element (6).

In order to find a direct link between p53 protein forms and regulation of H-ras, we examined the binding of the 'core' H-ras p53 element to: (i) wt p53 (ii) p53 mutant His 273 and (iii) wt p53 $\Delta 364-393$, a truncated protein which is activated for DNA binding (10). We showed that all three forms of p53 bind the H-ras-p53 element. Binding of the p53 to the same sequence of the H-ras oncogene has been successfully tested in nuclear extracts from head and neck tumors, as well. These results indicate that p53 could also function through the transcriptional regulation of the $\mathrm{H}$-ras oncogene. 


\section{Materials and methods}

Recombinant plasmids. Plasmid pSV2hp53B encoding fulllength human wild-type p53 contains the EcoRI-HindIII fragment of pGEM53wtB (26), blunt-ended and cloned in pSV2 vector cut with SalI-BglII. Plasmid pSV2hp53BHis273 was derived by site-directed mutagenesis (27) from pSV2hp53B and encodes full-length P53 protein with single point mutation; Arg 273 to His. Plasmid pGEMhp53B 4364 393 encodes human P53 protein with a deletion spanning residues 364-393.

Cell culture and transfection. Human osteosarcoma (Saos-2) cells were propagated in RPMI medium containing $10 \%$ fetal calf serum, supplemented with $100 \mathrm{U} / \mathrm{ml}$ penicillin and $100 \mu \mathrm{g} / \mathrm{ml}$ streptomycin, in a humidified atmosphere of $95 \%$ air and $5 \% \mathrm{CO}_{2}$ at $37^{\circ} \mathrm{C}$. Transfections were performed using the calcium phosphate technique (28), as modified (29). Briefly, semi-confluent exponentially growing cells were transfected with $40 \mu \mathrm{g}$ of plasmid DNA. Cells were collected by scraping 2-3 days later and used for preparation of nuclear extracts.

Preparation of nuclear extracts. Nuclear extracts were prepared from biopsy material obtained from patients who had undergone head and neck surgery at the Hippokration Hospital, Athens, Greece, and from transfected and untransfected Saos-2 cells. The above tissues and cells were homogenized in hypotonic buffer (25 mM Tris $\mathrm{HCl} \mathrm{pH} 7.5,5$ $\mathrm{mM} \mathrm{KCl}, 0.5 \mathrm{mM} \mathrm{MgCl}$, 0.5 mM DTT, 0.5 mM PMSF). The nuclei were pelleted, washed with isotonic buffer (25 $\mathrm{mM}$ Tris $\mathrm{HCl}, \mathrm{pH} 7.5,5 \mathrm{mM} \mathrm{KCl}, 0.5 \mathrm{mM} \mathrm{MgCl}, 0.5 \mathrm{mM}$ DTT, $1 \mathrm{mM}$ PMSF, $0.2 \mathrm{mM}$ sucrose) and lysed with an extraction buffer (25 mM Tris $\mathrm{HCl}, \mathrm{pH} 7.5,1 \mathrm{mM}$ EDTA, $0.1 \%$ Triton, $0.5 \mathrm{mM}$ DTT, $0.5 \mathrm{mM}$ PMSF). Nuclear debris was removed by centrifugation at $25,000 \mathrm{rpm}$ for $1 \mathrm{~h}$ at $4^{\circ} \mathrm{C}$. The protein concentration of the supernatant was measured by the method of Bradford (30).

Oligonucleotides and labelling. Oligonucleotide BC contains the optimal p53 binding site: 5'-CC-GGGCA-TGTCCGGGCA-TGTCC-GGGCATGT-3' (26). Oligonucleotide BC-S21 contains 21 spacers between the p53 half sites: 5'TAT-GGGCA-TGTCC-TATATATATGCGTATATAT AT-GGGCA-TGTCC-TAT-3' (26). Eras 2HS probe contains the two contiguous half sites with HindIII compatible ends: 5' - AGCTTGGCAC-TAGCC-TGCCC-GGGCA-CGCCGTGGCGA-3'. MDM-2 oligonucleotide contains the p53 binding element 5'-GGCT-GGTCA-AGTTG-CGTCC GGCGTCGGCTGTCGGAG-GAGCT-A-AGTCC TGACA-TGTCT-CCAG-3' of $m d m-2$ gene (31). The pentanucleotide p53 binding repeats are underlined. SP-1 oligonucleotide was used as a p53-unrelated oligonucleotide competitor (32). Radioactive end labelling was performed using T4 polynucleotide kinase (Boehringer) and $\left[\gamma-{ }^{32} \mathrm{P}\right]-\mathrm{ATP}$ (33).

DNA binding assay. DNA binding reactions were carried out as described (31) with modifications (10). The samples were electrophoresed on $6 \%$ polyacrylamide gels. Gels were dried and exposed to X-ray film (RX Fuji) at $-70^{\circ} \mathrm{C}$. A 50 fold molar excess of unlabelled oligonucleotides, or $0.4 \mu \mathrm{g}$ of anti-p53 antibody pAb 1801 (Oncogene Science, Inc, Manhasset, NY), or $0.4 \mu \mathrm{g}$ of anti-p53 antibody DO-1 (kindly provided by Dr D.P. Lane, Dundee, UK) were included prior to the addition of the radiolabelled probe in the reaction mixture, where indicated, and incubated at $0^{\circ} \mathrm{C}$ for $10 \mathrm{~min}$.

Western blotting. Western blotting was performed using $0.5 \mu \mathrm{g}$ anti-p53 DO-1 antibody at a dilution of 1:200, using the ECL kit (Amersham), following the instructions of the manufacturer.

DNA extraction, LOH, PCR-SSCP analysis. Genomic DNA from head and neck tumors and adjacent normal tissues was extracted by methods previously described (33). The three microsatelite primers (D17578, TP53 and CHRNB1) and PCR conditions, used for loss of heterozygosity (LOH) studies on 17 chromosome have been previously described (34). The fragment of the p53 gene, containing exons 4 to 9 $(2.9 \mathrm{~kb})$, was amplified by the polymerase chain reaction (PCR), using primers and conditions as described previously $(35,36)$. The first PCR product (amplified DNA size, $2.9 \mathrm{~kb}$ ) was used for the nested PCR-SSCP analysis. Briefly, two microliters of the $2.9 \mathrm{~kb}$ product were combined with $5 \mu \mathrm{l}$ $10 \mathrm{X}$ buffer, $1 \mu \mathrm{d} \mathrm{dNTP}$ mixture and $0.4 \mu \mathrm{M}$ of both primers in a final volume of $50 \mu \mathrm{l}(35,36)$. Five $\mu \mathrm{l}$ of the PCRamplified product was added to an equal volume of stop solution (95\% formamide, $20 \mathrm{mM}$ EDTA, $0.05 \%$ bromophenol blue, and $0.05 \%$ xylene cyanol) (United States Biochemicals, Ohio). Samples were denaturated at $95^{\circ} \mathrm{C}$ for 10 min, placed immediately on ice and run on an $8 \%$ polyacrylamide nondenaturing gel. DNA was electrophoresed in $0.5 \mathrm{X}$ TBE running buffer at 12 to $15 \mathrm{~W}$ at room temperature. Gels were visualized using the silver staining technique (37).

\section{Results}

A computer search revealed that the human $\mathrm{c}-\mathrm{H}$-ras gene contains two contiguous putative p53 half sites $(6,25)$. Transient transfection assays were used in this study to examine DNA binding activity of wild-type and mutated forms of P53 protein in the H-ras element. Endogenously produced wild-type and mutant p53 from head and neck tumors and adjacent normal tissue were also analysed for in vivo DNA binding.

Human osteosarcoma (Saos-2) cells, which have deleted endogenous p53 alleles (38), were transfected with plasmids coding the full length wild-type p53, wild-type p53 with a deletion which spans the last 30 amino-acid residues $(\Delta 364$ 393 ), and full-length p53 protein with single point mutation: Arg 273 to His (His 273). The resulted nuclear extracts were tested for p53 expression with immunoblotting, using antip53 antibody DO-1 (Fig. 1). Extract from untransfected Saos-2 cells was used as negative control (lane 1). Extracts containing full-sequence wild-type and ( $\Delta 364-393)$ p53 (lanes 2 and 3), as well as mutant form $\mathrm{H} 273$ of the protein (lane 4), showed a detectable amount of P53 protein.

$\mathrm{H}$-ras-p53 element was then tested for binding of the wild-type P53 protein. In Fig. 2, the control BC probe (lane 1) 


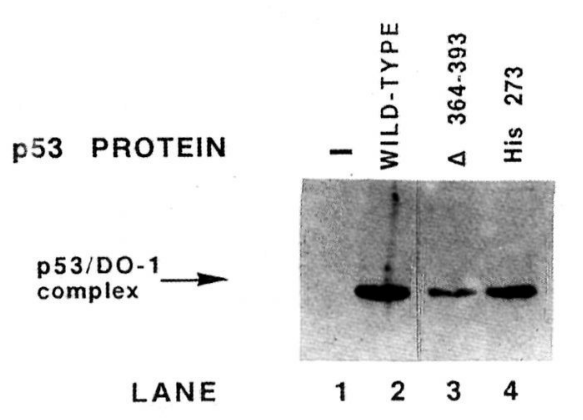

Figure 1. Western blot analysis of $\mathrm{p} 53$ expression. Nuclear extracts were prepared after transient transfection of Saos-2 cells with plasmids encoding full length wild-type p53 (lane 2), ( $\Delta 364-393$ ) p53 (lane 3 ) and mutant His 273 (lane 4) Extract from untransfected Saos-2 cells was used as negative control (lane 1). Thirty $\mu \mathrm{g}$ of total protein were subjected to immunoblotting in each lane. Anti-p53 DO-1 antibody was used for immunoblotting, as described in Materials and methods.

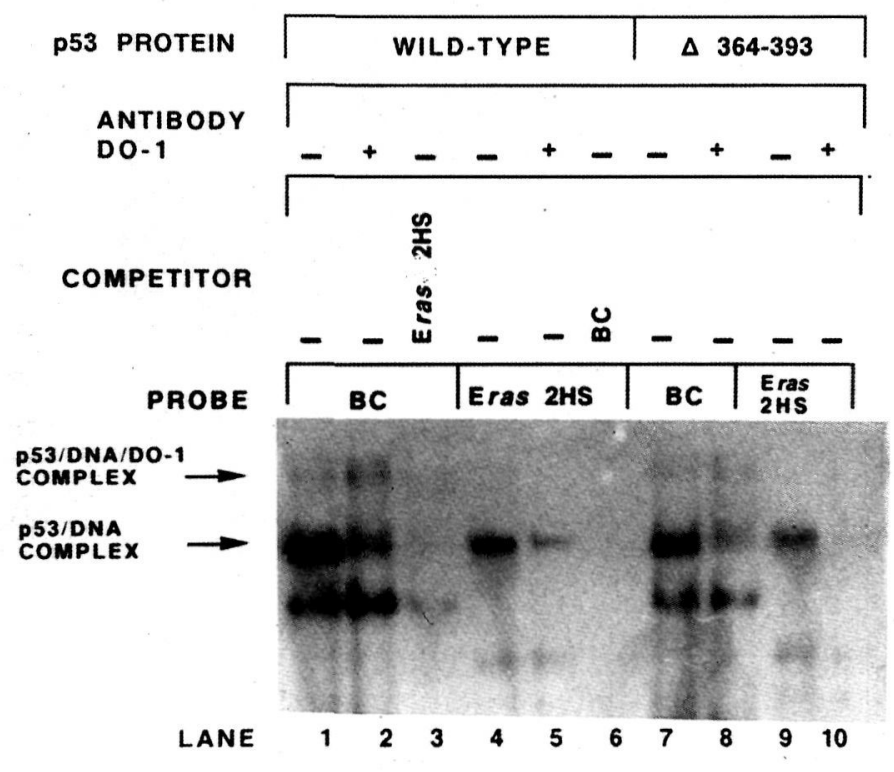

Figure 2. Sequence specific binding of wild-type $\mathrm{p} 53$ protein to the $\mathrm{H}$-ras element. After transfection of Saos-2 cells, full length (lanes 1-6) and truncated (lanes 7-10) forms of $\mathrm{p} 53$ protein were used in DNA binding assay. Binding reaction mixture contained $20 \mu \mathrm{g}$ of total protein, 0.01 pmoles of ${ }^{32} \mathrm{P}-1$ labelled probes BC (lanes 1-3 and 7-8) and Eras 2HS (lanes $4-6,9-10), 0.4 \mu \mathrm{g}$ anti-p53 antibody (lanes $2,5,8,10$ ) and a 50 fold molar excess over the labelled probe of unlabelled competitors (lanes 3, 6). Protein-DNA complexes were separated by polyacrylamide gel electrophoresis and visualized by autoradiography. p53/DNA complex is indicated by an arrow.

and the radiolabelled Eras $2 \mathrm{HS}$ probe (lane 2) were incubated with wild-type P53 protein. A common retarded band was observed, indicating binding of the protein to the probe. This band was supershifted/or abolished when antip53 DO-1 antibody was included in the reaction mixture (lanes 2 and 5) and abolished with competition of the probes with a molar excess of unlabelled oligonucleotides (lanes 3 and 6). Activated, truncated P53 protein p53 $364-393$ also

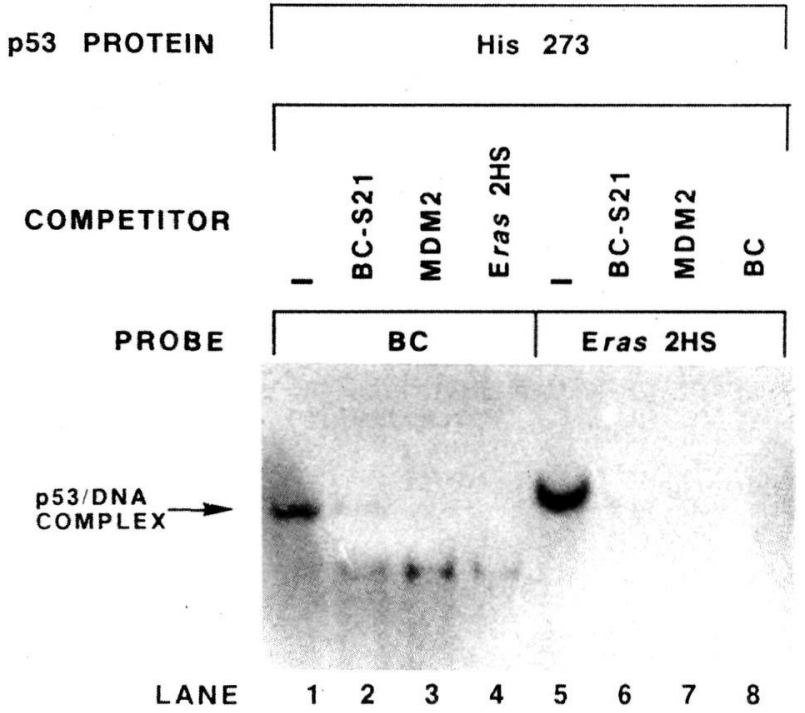

Figure 3. Sequence specific binding of mutant form of $\mathrm{p} 53$ protein His 273 to the H-ras DNA. His 273 p53 mutant, was analyzed after transfection of Saos- 2 cells. Binding reaction mixture contained $20 \mu \mathrm{g}$ of total protein, 0.01 pmoles of ${ }^{32} \mathrm{P}-1$ labelled probes BC (lanes 1-4), Eras 2HS (lanes 5-8) and a 50 fold molar excess over the labelled probe of unlabelled competitors (lanes 2-4 and 6-8 respectively). Protein-DNA complexes were separated as indicated in Fig. 2 legend. p53/DNA complex is indicated by an arrow.

reacted with BC (lane 7) and Eras 2HS probe (lane 9) and the P53/DNA complex was abolished by DO- 1 antibody (lanes 8 and 10).

His 273 'hot spot' mutant was also tested for binding H-ras-p53 element. The p53 mutant was incubated with control BC (Fig. 3, lane 1) and Eras 2HS (lane 5) probes, indicating binding of mutated P53 protein. The retarded band in both control and Eras 2HS probes was abolished in the presence of molar excess of p53-related oligonucleotide competitors BC-\$21 (lanes 2 and 6), MDM2 (lanes 3 and 7), Eras 2HS (lane 4) and BC (lane 8), implying the specificity of the p53-DNA complex.

Having established that all of the examined head and neck tumors and adjacent normal tissues had detectable P53 protein by Western blot analysis (data not shown), we tested the samples for binding to H-ras p53 element. Indicatively, five head and neck tumors and adjacent normal tissues were analysed. As shown in Fig. 4, a common retarded band was observed in the majority of the examined cases, indicating binding of the p53 protein to the H-ras responsive element. In all normal tissue samples we observed binding of p53 to the H-ras-p53 sequence. In contrast, 2 of the 5 tumor samples (Nos. 4 and 5) contained no p53 binding activity.

Specificity of the p53/ras DNA complex was shown by competition experiments, using nuclear extracts from tumor and normal tissue of patient No. 1 (Figs. 5 and 6, respectively). The labelled control BC-S21 (lanes 1-3) and Eras 2HS oligos (lanes 4-6), were incubated with a molar excess of unlabelled oligonucleotide competitors: with each other (Fig. 5, lanes 2,5) and with unrelated SP-1 oligonucleotide (lanes 3,6). Binding of p53 on Eras 2HS probe was abolished in the presence of excess BC-S21 competitor, 


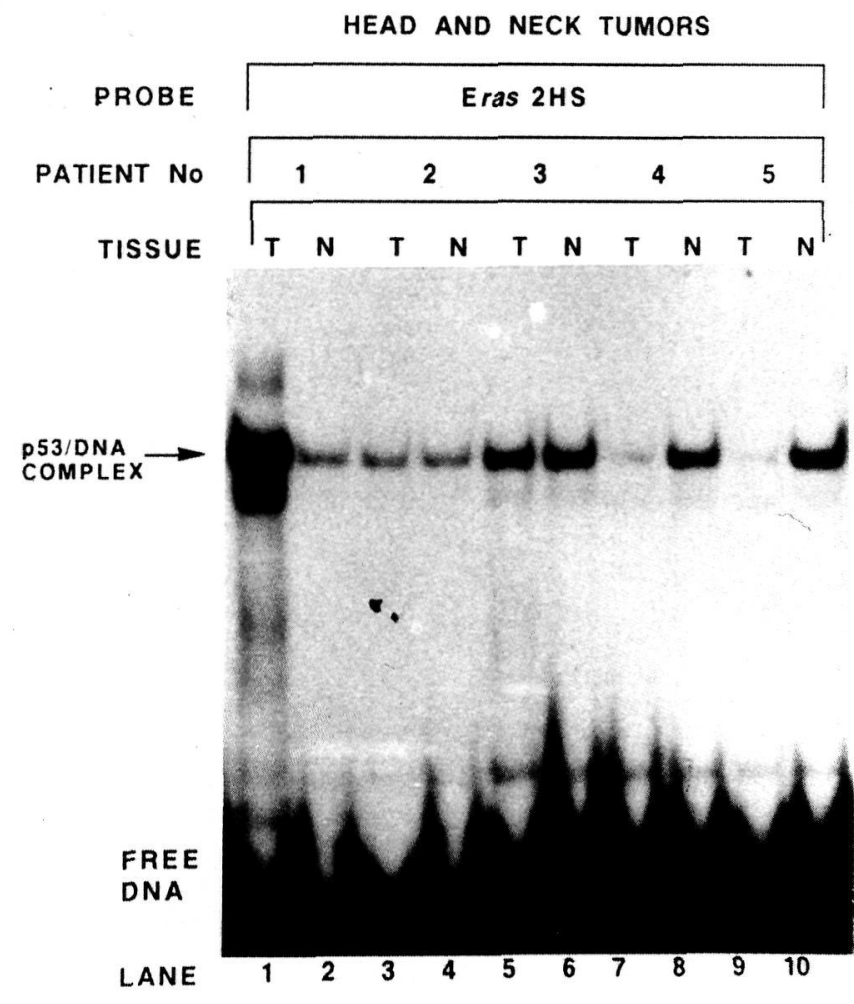

Figure 4. Sequence specific binding of endogenously produced $\mathrm{p} 53$ protein from head and neck tumors to H-ras element. Nuclear extracts from head and neck carcinomas were incubated with 0.01 pmoles of $y_{-}{ }^{32} \mathrm{P}$-end-labelled probe Eras 2HS (lanes 1-10). Protein-DNA complexes were separated as indicated in Fig. 2 legend. Protein-DNA complex is indicated by an arrow. $\mathrm{T}$, tumor; $\mathrm{N}$, normal tissue.

Table I. Loss of heterozygosity analysis of five head and neck tumors in chromosome 17 using PCR microsatellite primers.

\begin{tabular}{lccccc}
\hline & \multicolumn{5}{c}{ Patient number } \\
& 1 & 2 & 3 & 4 & 5 \\
\hline D175578 & 0 & 0 & $\varnothing$ & $\bullet$ & $\bullet$ \\
TP53 & 0 & 0 & $\varnothing$ & $\bullet$ & $\bullet$ \\
CHRNB1 & 0 & 0 & $\varnothing$ & $?$ & $\bullet$ \\
\hline
\end{tabular}

○, constitutional heterozygosity with no loss of heterozygosity; $\varnothing$, homozygous; •, constitutional heterozygosity with loss of heterozygosity; ?, not done.

but was unaffected by the unrelated SP-1 competitor. Equivalent results were observed from the control BC-S21 probe.

We subsequently studied the formation of the DNAprotein complex between Eras 2HS or BC-S21 and the p53 nuclear extracts from head and neck normal tissue (Fig. 6, lanes 1 and 3). Inclusion of the anti p53 1801 antibody into the reaction mixture led to the disapperance of the specific retarded band (Fig. 6, lanes 2 and 4).

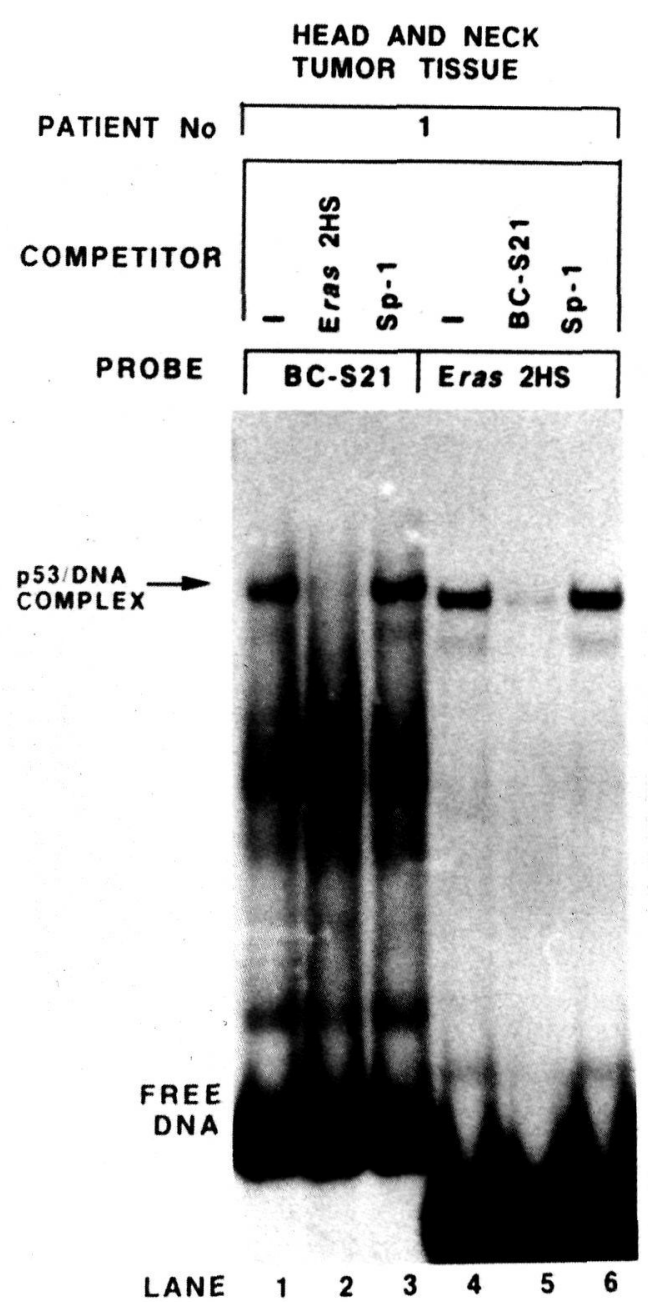

Figure 5. Effect of competitor sequences on gel electrophoretic mobility assay. Nuclear extracts from head and neck tumor tissue (patient No. 1) were incubated with $\gamma^{32} \mathrm{P}$-end labelled BC-S21 and Eras 2HS oligonucleotide hybrids. In competition assays, 50-fold molar excess of cold competitor oligonucleotides Eras 2HS, SP-1 (lanes 2, 3) and BC-S21, SP-1 (lanes 5,6 ) respectively, were incubated with the nuclear extracts before addition of the probes. Protein-DNA complexes were separated as indicated in Fig. 2 legend. Specific retarded bands of interest are shown.

Furthermore, we have analyzed five head and neck tumor tissues for loss of heterozygosity (LOH) in chromosome 17. The results are summarized in Table I. Also we analyzed the same samples for mutations in exons 4 to 9 of the p53 gene, as the majority of previous studies have shown that the $\mathrm{p} 53$ mutations in human tumors are found in this region (12). We first determined the optimal conditions for PCR amplification of the $2.9 \mathrm{~kb}$ p53 gene fragment. In order to exclude mutations caused by Taq polymerase the SSCP analysis was carried out on two different occasions for each tumor sample. The SSCP results are shown in Fig. 7. Three of the tumor samples (patient Nos. 1, 4 and 5) showed different pattern of bands in comparison with corresponding normal samples. No mutations were found by this method in two other samples (patient Nos. 2 and 3).

\section{Discussion}

In this study we examined the responsiveness of a p53 binding element, located in the $\mathrm{H}$-ras gene, to the wild-type, 


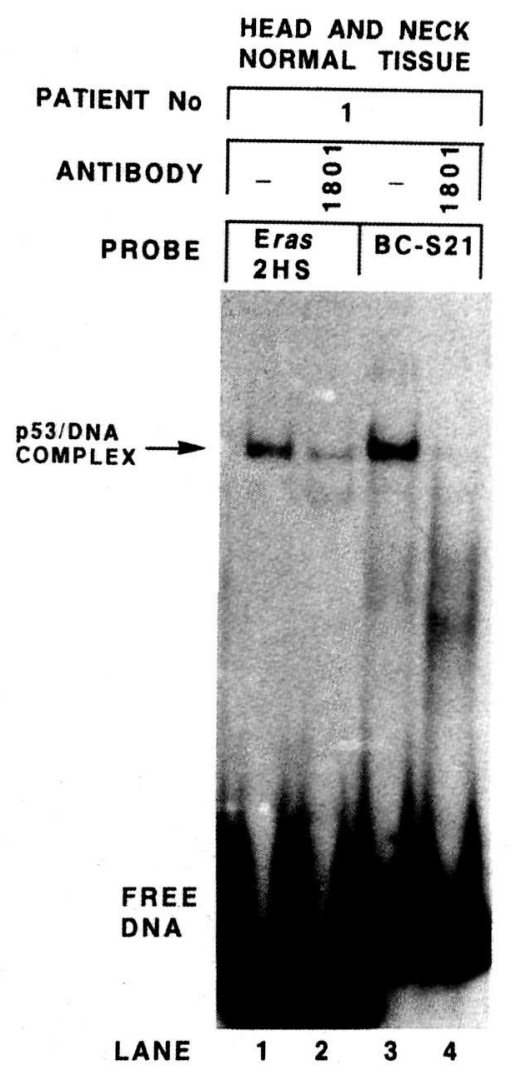

Figure 6. Effect of anti-p53 1801 antibody p53-ras DNA complex in electrophoretic gel mobility shift assay. Nuclear extracts from head and neck normal tissue (patient No. 1) were incubated with Eras 2HS oligonucleotide (lane 1) and BC-S21 oligonucleotide (lane 3). The anti-p53 antibody 1801 and nuclear extracts were incubated with Eras 2HS (lane 2) and BC-S21 (lane 4), respectively. Protein-DNA complexes were separated as indicated in Fig. 2 legend. Absence of the retarded band is shown. DNA-p53 complex is indicated by the arrow.

a mutant and a truncated form of P53 protein. This element consists of two contiguous p53 half sites (1216-1235) at the 3 ' end of the first intron of the H-ras gene (25).

In order to examine the responsiveness of the element to each wild-type, mutant and truncated p53 protein, we transfected plasmids encoding wild-type p53, the mutant His 273 and the truncated $(\Delta 364-393)$ form of p53 protein into p53-null Saos-2 cells. Nuclear extracts from the tranfectants were used in DNA binding experiments. Furthermore, we extended our studies in vivo using nuclear extracts from 5 head and neck tumors. Three of them possessed a mutant p53, two of which were accompanied by a deletion in the remaining allele.

Successful transfection was determined by immuno-blot analysis. Electrophoretic mobility shift assays with wild-type and truncated p53 transfected extracts, revealed specific binding of P53 protein to the $\mathrm{H}$-ras element, without adding monoclonal antibody PAb421 into the reaction mixture. Other groups have already shown that wild-type p53 can bind to certain DNAs $(6,26,39)$.

In addition, deletion of residues 364-393 has a similar effect in protein conformation as PAb421, because a negative regulatory element of the protein is removed, shifting the

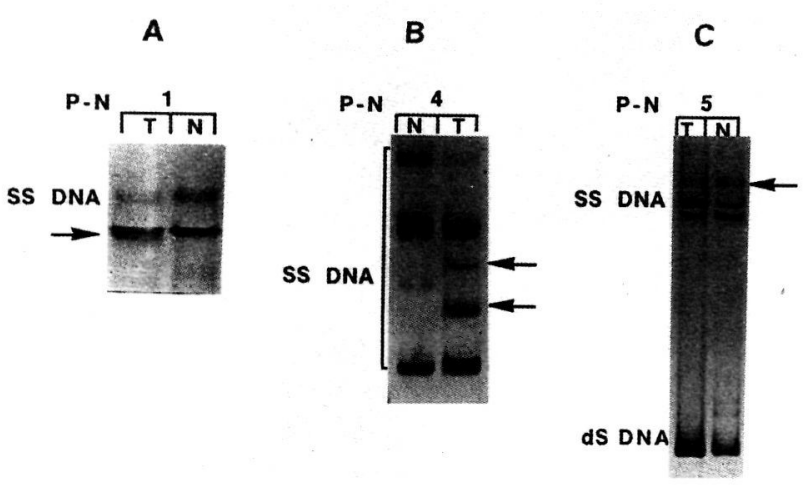

Figure 7. SSCP analysis of exons 6, 5 and 7 of p53 gene in head and neck specimens. Aliquots of $5 \mu \mathrm{l}$ of the PCR amplified samples were loaded on an $8 \%$ polyacrylamide nondenaturing gel. DNA was electrophoresed according to the conditions described in Materials and methods. PCR products from tumor DNA (A, exon 6; B, exon 5; C, exon 7) gave different patterns compared to normal DNA. PN, patient number; N, normal, T, tumor; ds, double stranded; ss, single stranded. Arrows indicate the different bands.

conformation to the active state $(26,40)$. The specificity of the retarded band, was confirmed by supershifting and/or abolishing when DO-1 antibody was included in the reaction. Furthermore, competition with molar excess of unlabelled related oligonucleotides abolished it.

Based on recent reports providing evidence for specific DNA binding of p53 mutants $(39,41-47)$, we examined the binding of His 273 mutant, which is known to be a 'gain of function' mutant, to the H-ras DNA $(43,46,48)$. Arg 273 is located in the loop sheet helix 2 motif which interacts with the major DNA groove and is primarily involved in DNA backbone contacts with phoshate groups (49). DNA binding experiments with His 273 , revealed a retarded band similar to that of wild type and truncated ( $\Delta 364-393) \mathrm{p} 53$, which was abolished when H-ras RE competed with p53 related oligonucleotides. The discrepancy between these results and earlier studies (25) may relate to the levels of P53 protein and/or the presence of cellular proteins in the nuclear extracts derived from tumor cells. It is possible that cellular factors induce DNA binding of the p53 mutant.

These experiments established this region of the H-ras gene as a specific p53 binding site and led us to a series of experiments focusing on the reaction of nuclear extracts derived from human tumors with H-ras-p53 RE. We examined five head and neck tumors, two of which (patient Nos. 4 and 5) had mutations in exons 5 and 7, respectively, accompanied by $\mathrm{LOH}$ in the p53 locus. Sample 1 (patient No. 1) had a mutation in exon 6 without $\mathrm{LOH}$ and the remaining two (patient Nos. 2 and 3 ) had no obvious p53 gene alterations.

DNA binding experiments revealed a retarded band, similar to that previously described in tumors 1,2 and 3 and in all normal tissues, while in tumors 4 and 5 there was no indication of band shift. The P53-specific antibody PAb 1801 inhibited DNA binding confirming the identity of the DNA binding protein as P53. The ability of PAb 1801 to suppress DNA binding of P53 has been documented previously (6). 
The biological explanation of these findings rely on the nature of the P53 protein in each of these tumors. In case 1 (patient No. 1), one p53 allele is mutant while the other is intact. Enhanced binding of P53 to the H-ras-p53 RE in this tumor sample probably relates to overexpression of the mutant P53 protein, combined with expression of wild-type P53. Probably the p53 mutant in this tumor retains its ability to bind DNA. In cases 2 and 3 (patient Nos. 2 and 3), p53 alleles are intact thus wt p53 binds the element. Finally, in cases 4 and 5 (patient Nos. 4 and 5), where one allele is lost, the remaining $\mathrm{mt}$ p53 is not capable of binding the consensus. The latter is enforced by the fact that in these specimens mutations were located in exons 5 and 7. Exons 5 and 7 form the L2 H1 L3 motif which interacts with the minor groove of the DNA. Mutations in these exons are considered to be among the most disruptive to p53 binding function.

Binding of the p53 to H-ras responsive element has been found with nuclear extracts from lung tumors, as well (Zoumpourlis et al, unpublished data).

In conclusion, we showed that the $\mathrm{H}$-ras gene possesses a p53 responsive element which interacts with wt and mutant forms of P53 protein in human tumors. Regulation of H-ras cellular oncogene by p53 opens new perspectives in understanding normal signal transduction pathway and its altered pathways in carcinogenesis.

\section{Acknowledgements}

We would like to thank Dr D. Lane for providing the antip53 DO-1 antibody.

\section{References}

1. Donehower LA and Bradley A: The tumor suppressor p53. Biochem Biophys Acta 1155: 181-205, 1993.

2. Levine AJ, Perry ME, Chang A, Silver A, Dittmer D, Wu M and Welsh D: The 1993 Walter Hubert Lecture: The role of p53 tumour-suppressor gene in tumorigenesis. Br J Cancer 69: 409416, 1994.

3. Rotter V, Aloni-Grinstein R, Schwartz D, Elkind NB, Simons A, Wolkowicz R, Lavigne $M$, Beserman $P$, Kapon $A$ and Goldfinger N: Does wild-type p53 play a role in normal cell differentiation? Semin Cancer Biol 5: 229-236, 1994.

4. Wyllie AH: The genetic regulation of apoptosis. Curr Opin Gen Dev 5: 97-104, 1995.

5. Tokino T, Thiayalingam S, El-Deiry WS, Waldman T, Kinzler KW and Vogelstein B: p53 sites from human genomic DNA. Hum Mol Gen 3: 1537-1542, 1994.

6. Funk WD, Pak DT, Karas RH, Wright WE and Shay JW: A transcriptionally active DNA-binding site for human $\mathrm{p} 53$ protein complexes. Mol Cell Biol 12: 2866-2871, 1992.

7. Kastan MB, Zhan Q, El-Deiry WS, Carrier F, Jacks T, Walsh WV, Plunkett BS, Vogelstein B and Fornace Jr AJ: A mammalian cell cycle checkpoint pathway utilizing p53 and GADD45 is defective in ataxia-telangiectasia. Cell 71: 587-597, 1992.

8. El-Deiry WS, Tokino T, Velcuscu VE, Levy DB, Parsons R, Tzent JM, Lin D, Mercer WE, Kinzler KW, Vogelstein B: WAF1, a potential mediator of p53 tumor suppression. Cell 75: 817-827, 1993

9. Chen CY, Oliner JD, Zhan Q, Fornace Jr AJ, Vogelstein B and Kastan MB: Interactions between p53 and MDM2 in a mammalian cell cycle check-point pathway. Proc Natl Acad Sci USA 91: 2684-2688, 1994.

10. Halazonetis TD and Kandil AN: Conformational shifts propagate from the oligomerization domain of p53 to its tetrameric DNA binding to select p53 mutants. EMBO J 12: 5057-5064, 1993.
11. Bargonetti J, Mantedi X, Chen DR, Marshak DR and Prives C: A proteolytic fragment from the central region of $\mathrm{p} 53$ has marked sequence-specific DNA-binding activity when generated from wild-type but not from oncogenic mutant $\mathrm{p} 53$. Genes Dev 7: 2565-2574, 1993.

12. Greenblatt MS, Bennett WP, Hollstein M and Harris C: Mutations in the p53 tumor suppressor gene: Clues to cancer etiology and molecular pathogenesis. Cancer Res 54: 48554878, 1994.

13. Londlow JW: Interactions between SV40 large-tumor antigen and the growth tumor suppressor proteins pRB and p53. FASEB J 7: 866-871, 1993.

14. Vousden K: Interactions of human papilloma virus transforming proteins with the products of tumor suppressor genes. FASEB J 7: 872-879, 1993.

15. Moran E: Interaction of adenoviral proteins with $\mathrm{pRB}$ and $\mathrm{p} 53$. FASEB J 7: 880-885, 1993.

16. Maxwell SA and Roth JA: Posttranslational regulation of $\mathrm{p} 53$ tumor suppressor protein function. Crit Rev Oncogen 5: 27-57, 1994.

17. Kiaris H and Spandidos DA: Mutations of H-ras genes in human tumours. Int J Oncol 7: 413-421, 1995.

18. Spandidos DA and Wilkie NM: Malignant transformation of early passage rodent cells by a single mutated human oncogene. Nature 310: 469-475, 1984.

19. Spandidos DA: The human T24 Ha-ras 1 oncogene: a study of the effects of overexpression of the mutated ras gene product in rodent cells. Anticancer Res 6: 259-262, 1986.

20. Spandidos DA, Frame M and Wilkie N: Expression of the normal $\mathrm{H}$-ras 1 gene can suppress the transformed and tumorigenic phenotypes induced by mutant ras genes. Anticancer Res 10: 1543-1554, 1990.

21. Parada LF, Land H, Weinberg RA, Wolf D and Rotter V: Cooperation between gene encoding p53 tumor antigen and ras in cellular transformation. Nature 312: 649-651, 1984.

22. Hinds P, Finlay $C$ and Levine AJ: Mutation is required to activate the p53 gene for cooperation with the ras oncogene and transformation. J Virol 63: 739-746, 1989.

23. Hinds PW, Finlay CA, Quartin RS, Buker SJ, Fearon ER, Vogelstein B and Levine AJ: Mutant p53 cDNA from human colorectal carcinomas can cooperate with ras in transformation of primary rat cells: a comparison of the 'hot spot' mutant phenotypes. Cell Growth Diff 1: 571-580, 1990.

24. Finlay CA, Hinds PW and Levine AJ: The p53 proto-oncogene can act as a suppressor of transformation. Cell 57: 1083-1093, 1989.

25. Spandidos DA, Zoumpourlis V, Zachos G, Toas S and Halazonetis TD: Specific recognition of a transcriptional element within the human $\mathrm{H}$-ras proto-oncogene by the $\mathrm{p} 53$ tumor suppressor. Int J Oncol 7: 1029-1034, 1995.

26. Halazonetis TD, Davis LJ and Kandil AN: Wild-type p53 adopts a 'mutant'-like conformation when bound to DNA. EMBO J 12: 1021-1028, 1993.

27. Higushi R, Innis MA, Gelfand DH, Sninsky JJ and White TJ (eds): PCR protocols. In: A Guide to Methods and Applications. Academic Press, San Diego, CA pp177-183, 1990.

28. Graham FL and Van der Eb: A new technique for the assay of infectivity of human adenovirus 5 DNA. Virology 52: 456-467, 1973.

29. Spandidos DA and Wilkie NM: Expression of exogenous DNA in mammalian cells. In: In vitro Transcription and Translation A Practical Approach. Hames BD and Higgins S (eds). IRL Press, Oxford pp1-48, 1994.

30. Bradford MM: A rapid and sensitive method for the quantitation of microgram quantities of protein using the principle of protein-dye binding. Anal Biochem 72: 248-254, 1976.

31. Juven T, Barak Y, Zauberman A, George DL and Oren M: Wild-type p53 can mediate sequence-specific transactivation of an internal promoter within the $m d m 2$ gene. Oncogene 8: 3411 3416, 1993.

32. Zoumpourlis V, Ergazaki $M$ and Spandidos DA: AP-1 recognizes sequence elements on HIV-1 LTR in human epithelial tumor cell lines. Oncol Rep 1: 397-401, 1994.

33. Maniatis T, Fritsch EF and Sambrook J: Molecular cloning: A laboratory manual. Cold Spring Harbor Laboratory, Cold Spring Harbor, NY, 1989.

34. Adamson R, Jones AS and Field JK: Loss of heterozygosity studies on chromosome 17 in head and neck cancer using microsatellite markers. Oncogene 9: 2077-2082, 1994. 
35. Field JK, Zoumpourlis V, Spandidos DA and Jones AJ: p53 expression and mutations in squamous cell carcinoma of the head and neck: Expression correlates with the patients' use of tobacco and alcohol. Cancer Detect Prev 18: 197-208, 1994.

36. Gorgoulis V, Zoumpourlis V, Rassidakis G, Karameris A, Barbatis C, Spandidos DA and Kittas C: Molecular analysis of p53 gene in laryngeal premalignant and malignant lessions. p53 protein immunohistochemical expression is positively related to proliferating cell nuclear antigen labelling index. Virchows Arch 426: 339-344, 1995.

37. Bassam BJ, Caetano-Anolles G and Gresshoff PM: Fast and sensitive silver staining of DNA in polyacrylamide gels. Anal Biochem 196: 80-83, 1991.

38. Zambetti GP, Bargonetti J, Walker K, Prives C and Levine A: Wild-type p53 mediates positive regulation of gene expression through a specific DNA sequence element. Genes Dev 6: 1143$1152,1992$.

39. Zhang W, Guo X-Y D and Deisseroth AB: The requirement of the carboxyl terminus of p53 for DNA binding and transcriptional activation dependts on the specific p53 binding DNA element. Oncogene 9: 2513-2521, 1994.

40. Waterman JLF, Shenk JL and Halazonetis TD: The dihedral symmetry of the p53 tetramerization domain mandates a conformational switch upon DNA binding. EMBO J 14: 512$519,1995$.

41. Deb S, Jackson C, Subler MA and Martin DW: Modulation of cellular and viral promoters by mutant human p53 proteins found in tumor cells. J Virol 66: 6164-6170, 1992.
42. Chen J-Y, Funk WD, Wright WE, Shay JW and Minna JD: Heterogeneity of transcriptional activity of mutant p53 proteins and p53 target sequences. Oncogene 8: 2159-2166, 1993.

43. Zhang W, Funk WD, Wright WE, Shay JW and Deisseroth AB: Novel DNA binding of p53 mutants and their role in transcriptional activation. Oncogene 8: 2555-2559, 1993.

44. Zhang W, Shay JW and Deisserth A: Inactive p53 mutants may enhance the transcriptional activity of wild-type p53. Cancer Res 53: 4472-4775, 1993.

45. Zhang W, Guo X-Y, Hu G-Y, Liu W-B, Shay JW and Deisseroth $\mathrm{AB}$ : A temperature-sensitive mutant of human $\mathrm{p} 53$. EMBO J 13: 2535-2544, 1994.

46. Park DJ, Nakamura H, Chumakov AM, Said JW, Miller CW, Chen DL and Koeffler HP: Transactivational and DNA binding abilities of endogenous p53 in p53 mutant cell lines. Oncogene 9: 1899-1906, 1994

47. Niewolik D, Vojtesek B and Kovaric J: P53 derived from human tumour cell lines and containing dinstinct point mutations can be activated to bind its consensus target sequence. Oncogene 10: 881-890, 1995

48 Dittmer D, Pati S, Zambetti G, Chu S, Teresky A, Moore M, Finlay $\mathrm{K}$ and Levine A: Gain of function mutation of $\mathrm{p} 53$. Nature Genetics 4: 42-45, 1993.

49. Cho Y, Gorina S, Jeffrey PD and Paxletch NP: Crystal structure of a p53 tumor suppressor-DNA complex: Understanding tumorigenic mutations. Science 265: 346-355, 1994. 